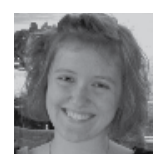

Tone Hærås, sykepleier og mastergradsstudent i sykepleievitenskap ved Universitetet i Oslo

\section{Sykepleierens evne til innlevelse i pasientens erfaringer, smerte, vonde og negative følelser er viktige komponenter $\mathrm{i}$ behandlingen.}

\section{Les mer og finn litteraturhenvisninger på www.sykepleien.no}

Søkeord:
Flyktning
Krig
Psykisk lidelse
Tortur
Stress

\title{
Omstridt behandling av posttraumatisk stress
}

\author{
EMDR-behandling av flyktninger som lider av posttraumatisk stress \\ er en omdiskutert, men etter hvert ganske utbredt metode.
}

I løpet av de siste årene har vi hatt en tidobling av antall flyktninger som oppholder seg i Norge (1). På bakgrunn av dette ser vi at helsevesenet møter mange utfordringer i forhold til innvandrerpasienter (2). Halvparten av innvandrere i Norge oppgir å bli diskriminert (3). Mange av disse pasientene sliter med Posttraumatisk stresslidelse (PTSD). Til enhver tid regner man med at cirka en prosent av befolkningen lider av PTSD (4).

\section{EMDR-behandling}

Behandlingsmetoden Eye movement desensitization and reprocessing (EMDR) ble først tatt i bruk av psykologen Francene Shapiro (5). Hun prøvde ut metoden på pasienter med PTSD og oppdaget at disse pasientene responderte veldig bra på behandlingen. Behandlingen kan foregå poliklinisk eller på institusjon. Den går ut på at helsepersonell beveger en finger frem og tilbake foran pasientens ansikt. Pasienten skal følge fingeren med øynene, samtidig som han eller hun blir bedt om å fremkalle bilder fra de traumatiske hendelsene på netthinnen. Videre ber behandler om at pasienten fors $\varnothing$ ker å forvandle disse traumatiske bildene til positive tanker. Pasienten responderer gjennom å formidle sin opplevelse av hvordan negativiteten rundt traumene reduseres i kroppen. Behandlingen er ferdig når pasientens stress angående traumet er redusert eller helt borte (6). Behandlingen skal bare utføres av kompetent helsepersonell (7).

\section{Metode}

I min bacheloroppgave ønsket jeg å se nærmere på hvorvidt det er forsvarlig å behandle PTSD-pasienter med EMDR. Vi valgte kvalitativt intervju (8) i kombinasjon med litteraturstudie, som metode. I forberedelsestiden før intervjuet skrev vi søknad til institusjonen om å få intervjue helsepersonell som arbeider med vår problemstilling. Intervjuet er anonymisert (9).

Sykepleierens mål er å hjelpe den syke til å utholde og mestre sykdom. Sykepleieren kan oppnå dette gjennom å hjelpe pasienten til å finne mening i sykdommen, dersom pasienten ikke er i stand til dette alene. Er dette mulig i alle situasjoner? (11). Intervjuobjektet påpekte at innvandrerpasientene med PTSD i utgangspunktet har vanskelig for å finne mening i det de har blitt utsatt for, og at de blir syke først når de kommer til Norge hvor de er trygge. Intervjuobjektet hadde en mulig forklaring på dette. Dette er interessant ettersom de fleste pasientene vet at krigen er over og at de forferdelige opplevelsene bare er grusomme minner. De vet at de ikke er i fare lenger, men de føler det ikke slik. Problemet har sitt utspring i den emosjonelle delen av hjernen, hvor sporet etter traumet ligger. Og den kognitive, rasjonelle delen av hjernen når ikke inn hit (12).

\section{Trygghet viktig}

EMDR-behandlingen av PTSD-pasienter har gitt raske, positive resultater. Også når det gjelder behandling av komplekse og krevende pasienter (6). Intervjuobjektet hevder at det er individuelt hvem som kan dra nytte av behandlingen. Dette er fordi behandlingen krever at pasienten har et trygt og godt minne å tenke tilbake på under behandlingen, når situasjonen blir for tøff. Det er dette som avgjør om behandlingen har effekt eller ikke. Enkelte PTSD-rammede innvandrere kan ha opplevd så mye vondt $\mathrm{i}$ livet at de ikke med sin beste vilje klarer å hente fram et trygt og godt minne. I slike tilfeller vil ikke behandlingen være aktuell, ifølge intervjuobjektet. Trygghet er hjørnesteinen i alt arbeid med traumatiserte flyktninger. Tryggheten kan bli truet fordi gode minner også inneholder et tapsaspekt. Dersom dette er tilfelle for innvandrerpasienten, kan EMDR-behandlingen likevel utføres, fordi pasienten har et godt minne. Vi ser da at behandlingen kan ha negative konsekvenser, i form av øt tapsfølelse og utrygghet (16).

Sykepleierens evne til innlevelse i pasientens erfaringer, smerte, vonde og negative følelser er viktige komponenter i behandlingen. Men dette kan også føre til medinnlevelsestretthet (compassion fatigue) hos behandler, både psykologisk og fysisk. En flyktning er en pasient i en livssituasjon de fleste norske sykepleiere ikke engang ønsker å få innblikk i. Likevel er det helt nødvendig at sykepleieren gjør nettopp dette. Da er det viktig at arbeidsledelsen $i$ institusjonen er god, slik at den enkelte behandler får variasjon i og 


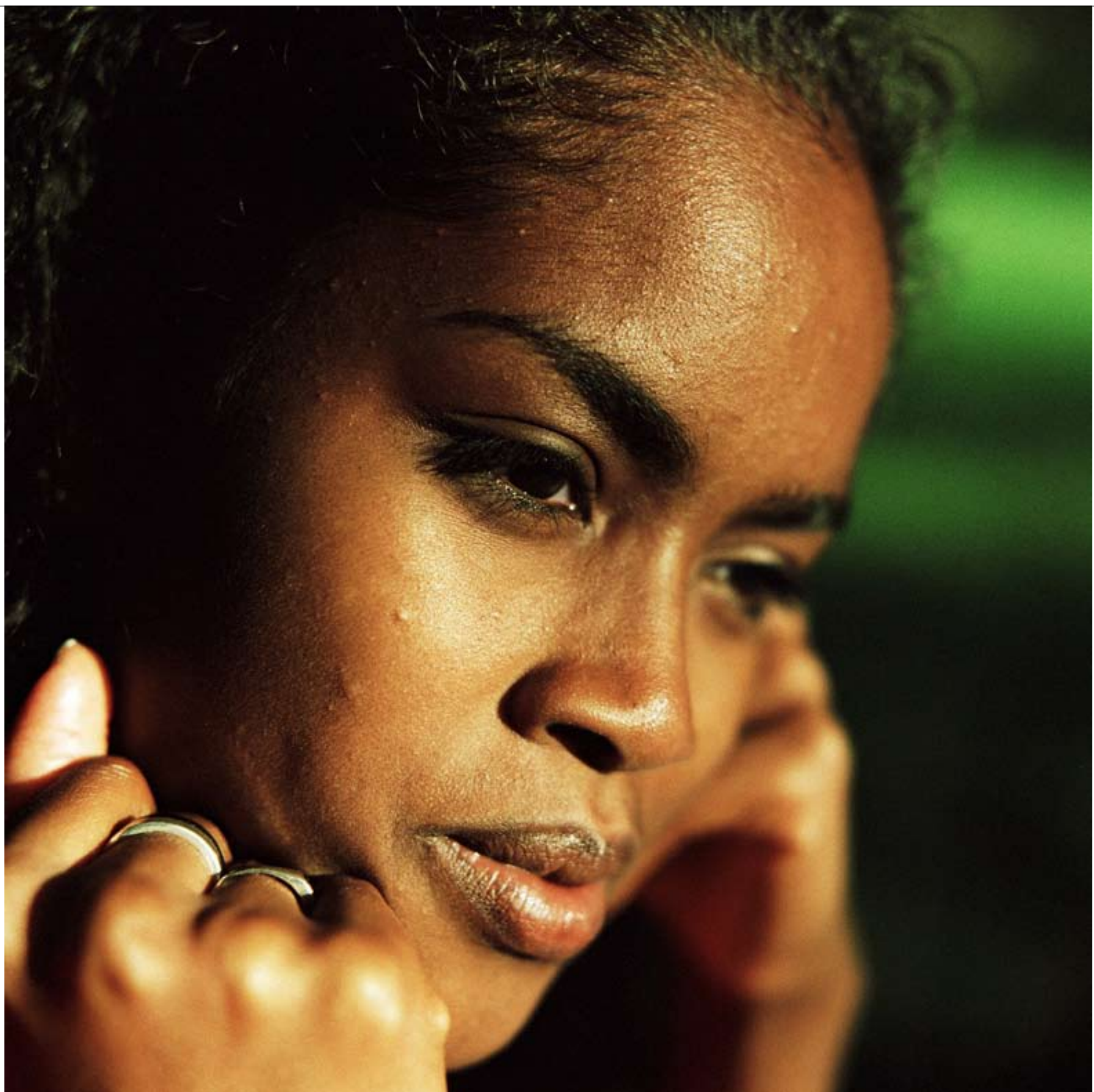

HAR KRIGSTRAUMER: I 2008 bodde det 132400 personer med flyktningbakgrunn i Norge. Mange av disse lider av posttraumatisk stress. Illustrasjonsfoto: Colourbox

innflytelse over arbeidet. Dette kan gjøres på ulike måter, for eksempel i form av undervisning, veiledning og stimuleringstiltak (16).

\section{Lite forskning}

EMDR er et verktøy som både behandler årsakene til symptomene og hjelper pasienten med å forholde seg til disse. EMDR-teknikken fjerner arret etter de vonde følelsene, og da forsvinner også som regel symptomene (12). Det er gjort lite forskning på EMDR-behandling. Er det slik at behandlingen kun er i bruk på grunn av god markedsføring? Det er også i liten grad vist til negative effekter av EMDR. Betyr dette er at behandlingen ikke har noen negativ effekt eller er den bare ikke dokumentert? I en undersøkelse ble det bare identifisert én negativ effekt hos en PTSDpasient som hadde gjennomgått EMDR-behandling.

Mange tviler på hvorvidt virkningen av behandlingen skyldes place- boeffekt. Selv helsearbeidere som arbeider aktivt med EMDR i møte med PTSD-pasienter klarer ikke å si nøyaktig hvordan behandlingen virker. Det er noe mystisk ved den. Dette har ført til at psykologen Shapiro har utarbeidet modeller for å forklare hvordan EMDR virker. Men disse modellene er det mange som er svært skeptiske til. Helsearbeideren går inn i en nær relasjon med pasienten, ved å la pasientens øyne følge fingerbevegelsene. Noen mener det er dette som gjør behandlingen effektiv (6).

\section{Spor etter smerte}

Det finnes en studie som ble gjort veldig tidlig i EMDR-behandlingens historie. En forsker tok røntgen- og CT-bilder av hodene til pasienter som gikk til EMDR-behandling på grunn av PTSD. Bildene viste at den delen av hjernen som arbeider med å skifte oppmerksomheten fra en ting til en annen, var svært aktiv 
etter slike behandlinger. Men det var få som var med i undersøkelsen og det var ingen kontrollgruppe, det er derfor mange som tviler sterkt på resultatet (6). Likevel, en undersøkelse utført ved avdelingen for psykiatri ved Harvard-universitetet viser at svært smertefulle opplevelser setter dype spor i hjernen. Den viser også hvordan dette sporet ser ut. Dette viser at mye av årsaken til sykdommen sitter i hjernen, og det er derfor viktig å forske på om behandlingen styrke ligger i at den først fremkaller minnets forskjellige bestanddeler, de visuelle, følelsesmessige, kognitive og fysiske. Deretter stimuleres tilpasningssystemet, altså øyebevegelsen, som skal bearbeide informasjonen, fordi minnet ikke har blitt fordøyd av seg selv. Dette skal bidra til å aktivere hjernens naturlige selvhelbredende funksjon. Noen forskere har vist at øyebevegelser gir «tvungen» avslapning som bidrar til en øyeblikkelig reduksjon i hjertefrekvensen

\section{EMDR er et verktøy som både behandler årsakene til symptomene og hjelper pasienten med å forholde seg til disse.}

har innvirkning på hjernen (12). En nyere og mer troverdig undersøkelse av PTSD-pasienter som har gått til EMDR, er gjort ved å ta blodprøver av dem. Blodprøvene inneholder stoffer som responderer på stress. Etter behandlingen kunne man se en endring i disse stoffene. Ytterligere forskning kan føre til kunnskap om biologiske mekanismer som endres ved EMDR. Dette kan kanskje føre til at vi til slutt kan forstå hvordan EMDR kan påvirke nevrologien $\mathrm{i}$ hjernen (6).

\section{Nevrologisk effekt}

Det nyeste gjennombruddet når det gjelder forskning på nevrologiske effekter av EMDR skyldes en søvnforsker ved navn Stickgold. Han har klart å finne ut av hvorfor disse øyebevegelsene er så effektive ved å koble dem til øyebevegelsene mennesket gjør under REM-søvnen (6). Dersom disse to typene øyebevegelser gir samme effekt - kan EMDR kobles sammen med mye god nevrobiologisk forskning på REM-søvnen. Samtidig er det også påvist effekt av EMDR ved at man lager lyder eller driver med annen påvirkning av pasienten i stedet for øyebevegelsene. Denne forskningen bidrar til å etablere en nevrobiologisk forklaring på EMDR-behandlingen. Per dags dato kan ingen si hundre prosent sikkert hvordan EMDR virker (6). Noen hevder at EMDR-behandlingens og en økning i kroppstemperaturen. Dette kan bety at EMDR stimulerer aktiviteter i det parasympatiske nervesystemet som får PTSD-symptomene til å forsvinne (12).

\section{Mangelfull forskning}

Generelt er mye av forskningen på EMDR-behandlingen mangelfull, som for eksempel: Manglende diagnostisk likhet hos pasienter, få pasienter per studie og manglende standardiserte målinger. Forskningen kan minne mer om idealisme enn om reell vitenskapelig forskning (6). Den franske psykiateren Servan-Schreiber var i begynnelsen svært skeptisk til EMDR. Det som overbeviste ham var resultatet av en undersøkelse, som ble offentliggjort i et av de mest seriøse tidsskriftene for klinisk psykologi, hvor åtti pasienter med store traumatiske lidelser ble behandlet med EMDR-teknikken. Konklusjonen viste at 80 prosent av pasientene ble kvitt sine posttraumatiske stressymptomer etter kun tre behandlinger. Da de samme åtti pasientene ble intervjuet femten måneder senere, var effekten enda bedre enn den hadde vært rett etter behandlingen (12).

I den mest brukte database for posttraumatiske stressymptomer, «Pilot Database» ble det i år 2000 registrert flere kontrollerte kliniske studier av EMDR-behandlingen enn noen andre behandlingsformer.
Som følge av dette ble det utført tre studier av alle de offentliggjorte studiene. Her kommer det frem at EMDR-teknikken er minst like effektiv som de beste behandlingsmetodene. Det kom også frem at den var den raskeste behandlingsmetoden og den som pasientene tålte best (12).

Likevel er EMDR en omstridt behandlingsmetode. Flere universitetsansatte, i for eksempel USA, beskriver den som en «mote» eller en «markedsføringsteknikk». Grunnen til dette er at det fremdeles ikke er noen som kan forklare nøyaktig hvordan EMDR virker. Slike reaksjoner som dette er ganske vanlige fenomener i medisinens historie. Dette gjelder særlig dersom behandlingen er «naturlig» eller "virker for enkel», noe som nettopp er tilfelle med EMDR-teknikken (12).

\section{Avslutning}

På grunnlag av enkelte begrensede forskningsmetoder som er gjennomført på området, er det i dag ikke mulig å være helt sikker på virkningen av EMDR på PTSDpasienter. Behandlingen har også likheter med andre effektive behandlingsformer. Dette gjør at EMDR-behandlingen ikke er i noen særklasse og det er heller ikke en gjennombruddsbehandling. EMDR er likevel påvist som klinisk effektivt, men er det nok til å kalle EMDR for forsvarlig behandling av PTSD-pasienter? Det er forskjell på vitenskap og klinikk. Dette gjenspeiles ved at helsepersonellet som bruker EMDR er helsepersonell med klinisk fokus, som ikke er så opptatt av forskning (6).

I dag er EMDR offisielt godkjent som en effektiv behandling av PTSDsymptomer av "American Psychological Association", den internasjonale organisasjonen for studier av traumatisk stress. Organisasjonen foreslår behandlingsmetoder for posttraumatiske stressymptomer på et etablert vitenskapelig (kunnskaps-) grunnlag (12). Det er også blitt opprettet en organisasjon ved navn, «EMDR Norge», som er tilsluttet organisasjonen «EMDR Europe».

\section{LITTERATUR}

1. Statistisk sentralbyrå. Befolkningsstatistikk (2007) http://www.ssb. no/emner/02/01/10/flyktninger/ (28.02.2008)

2. Sveaass N, Hauff H. Flukt og fremtid - psykososialt arbeid og terapi med flyktninger. Oslo: Ad Notam Gyldendal, 1997.

3. Blom S, Henriksen K. Levekår blant innvandrere i Norge 2005/2006. Statistisk sentralbyrå. http://www.ssb.no/emner/00/02/ rapp_200805/rapp_200805.pdf (28.02.2008).

4. Götestam GK, Thorsen O. Posttraumatisk stresslidelse. Legehåndboka. http://www.legehandboka. no/asp/document.asp?id=3126 (28.02.2008).

5. Bisson J. Eye movement desensitisation and reprocessing to treat PTSD. Clinical Evidence, 10. http:// clinicalevidence.bmj.com/ceweb/ conditions/meh/1005/1005_I10.jsp (29.02.2008).

6. McCabe S. EMDR: Implications of the Use of Reprocessing Therapy in Nursing Practice. Perspectives in Psychiatric Care 2004; 40 (3): 104-113.

7. Selle HS. Hva er EMDR? EMDR Norge. http://emdrnorge.com/ page1/index.html (01.04.2008). 8. Jacobsen DI. Forståelse, beskrivelse og forklaring - Innføring I samfunnsvitenskapelig metode for helse og sosialfagene. Kristiansand: Høyskoleforlaget,2003.

9. Helsinki-deklarasjonen. http:// www.etikkom.no/retningslinjer/helsinkideklarasjonen (01.04.2008). 10. Granum F, Solvoll BA. Sykepleieren - den forskende praktiker. Oslo: Tano Aschehoug, 1997.

11. Kirkevold M. Sykepleieteorier - analyse og evaluering. Oslo: AdNotam Gyldendal A/S., 1992. 12. Servan-Schreiber D. Evnen til helbred-Behandling av stress, angst og depresjon uten medikamenter eller psykoterapi. Oslo: Pax Forlag A/S., 2005.

13. Sveaass N, Johansen LEE. Drømmen bortenfor: Traumatiserte flyktningers møte med psykologisk behandling. Tidskr Nor Psykologiforen 2006; 43 (12): 1282-1291.

14. Pasientrettighetsloven. http:// www.lovdata.no/all/nl-19990702063.html (11.03.2008).

15. Ahlberg N, Duckert F. Minoritetsklienter som helsefaglig utfordring. Tidsskr Nor Psykologiforen 2006; 43 (12): 1276-1281.

16. Dahl S, Sveaass N, Varvin Psykiatrisk og psykososialt arbeid med flyktninger - veileder. Oslo: Unipub AS., 2006.

17. Selle HS. Hva er EMDR? EMDR Norge. http://emdrnorge.com/ page1/index.html 